\title{
Spring Meeting of the EPS Council
}

Geneva, 28-29 March 1974

On 28 and 29 March, 45 members of Council, Chairmen of Divisions and Advisory Committees, and invited delegates gathered at the Battelle-Geneva Research Center in Carouge for the only Council meeting of the European Physical Society to be held during 1974. For the coming year a meeting is planned for January 1975 in Amsterdam and a one day meeting on Monday, 8 September 1975 in Bucharest, preceeding the Third General EPS Conference.

In his opening remarks H.B.G. Casimir, President, reported on the results of his approaches for contributions from various out-side agencies, which yielded sofar about SFr. $10000 .-$. He invited all those present to join in the effort of collecting the "miracle-sum" of SFr. 300000 . - to solve the Society's financial problems. The President further reported on a decision of the Presidium of the Union of Czechoslovak Mathematicians and Physicists to close the Branch Secretariat in Prague as of 31 March 1974.

The preparation of the Third General EPS Conference - Energy and Physics - to be held on 9-12 September 1975 in Bucharest, is progressing; the programme of the Conference will be shaped at the second meeting of the Programme Committee to be held early June in Bucharest. Council recommended that special attention be given to attracting young physicists to Bucharest:

- $50 \%$ of the amount available in the EPS Conference Fund in September 1975 was to be spent as allowances to young people,

- an appeal to all Academies and National Societies, Members of EPS, was to be made, requesting them to find funds in their respective countries for allocations to young physicists attending the Bucharest meeting,

- the Romanian hosts to the EPS General Conference were able to secure Romanian government fellowships for a limited number of young participants to the Conference.

An Exhibition of Scientific Instruments is planned to be organized in conjunction with the General Conference.
Chairmen and delegates reported on the activities in their respective Divisions, in particular on the conferences and summerschools planned and organized by EPS Sections and Divisions (see the Meetings Issue to appear in May 1974). The Division on High Energy and Particle Physics reported on the successful experiment undertaken at the 2nd Aix-en-Provence International Conference on Elementary Particles, on 6-12 September 1973 , of bringing "physics into the street", making use of TV and mass media to communicate with non-physicists and organizing sessions to popularize High Energy Physics.

The important role EPS Divisions take within the Society was underlined and the following motion was accepted by Council:

"The Council notes the current and long-range importance of its constituent Divisions as the promoters of the physics-oriented activities of the EPS. Presently divisional aspects are recognized by the automatic invitation of Chairmen of Divisions to attend Council meetings.

The Executive Committee is instructed to review the extent to which the Divisions are able to exercise influence on the policy of the EPS as determined by Council, and to make recommendations whether any change of the Constitution is necessary or desirable. Such a change could be to extend Council membership ex officio to chairmen of Divisions."

A warning was expressed by representatives of Divisions against any further reduction of the Secretariat. When examining moving from the present premises it was felt to be essential to keep the Secretariat functional and to guarantee the safeguard of EPS's image.

Establishing a central service for printing and selling the abstracts of EPS Conferences to libraries and subscribers was recommended to be set up with high priority.

C.M. Braams, Vice Treasurer, reported on financial matters of the running year: expenses and income were satisfactorily within the limits of the approved budget. In view, however, of the accumulated debts and of inflation prevailing in Western European countries, he stressed that indexing of the unit fee was absolutely necessary to keep EPS from bankruptcy in the years to come.
A discussion on future activities of EPS was held by Council to meet the intervention, at the last Council meetnig, of B.J. Green, delegate of Individual Ordinary Members. The following motion emerged from the various suggestions discussed:

"Council requests the Executive Committee to set up forthwith a working group to consider, how information about the supply and demand of physicists in Europe could be collected and evaluated under the auspices of the EPS. This group should, in particular, try to answer the following questions:

1. What national surveys exist and to what extent are they comparable?

2. How an integrated European survey could be made?

3. How such a project could be financed?"

In addition the Executive Committee was instructed by Council to go ahead with the formation of an Advisory Committee on Education.

The Hellenic Physical Society applied to join the European Physical Society and was accepted by Council as 28th Member of the Society according Article $4 \mathrm{~b}$ ) of the Constitution.

Council also approved the change of Constitution proposed at its latest meeting in November (see also Europhysics News, Vol. 4, No. 11). Ordinary Members of the European Physical Society are herewith informed that the new wording of Article 19.2 of the Constitution reads:

"Members of the Executive Committee may be immediately reelected but shall not serve more than five years".

The new Executive Committee taking office on 1 April 1974 was elected as follows:

President

H.B.G. Casimir,

Eindhoven

Vice-President G. Szigeti, Budapest

Secretary J.J. Went, Arnhem

Vice-Secretary T. Riste, Kjeller

Treasurer O.S. Heavens, York

Vice-Treasurer M. Guenin, Geneva

Members N. Cindro, Zagreb

J. Friedel, Paris

K. Ganzhorn, Stuttgart

I. Ursu, Bucharest

B.M. Vul, Moscow

L. Etienne-Amberg, Editor. 
In the past there have been some uncertainties as to the status of the relations between the European High Pressure Research Group (EHPRG) and the Condensed Matter Division (CMD) of the European Physical Society (cf. Europhysics News, Vol. 4, No. 2, p. 1, February 1973). The undersigned wish to elucidate the situation.

The European High Pressure Research Group is in existence since 12 years. Its main activity is to organize one scientific conference every year.

After the Condensed Matter Division of EPS had been founded an affiliation of EHPRG to CMD was thought to be profitable. EHPRG would take care of scientific conferences in its field and thus would work like a section of CMD. Moreover, it was hoped that EHPRG may become an affiliated section of CMD. Because of the strict rules of EPS it was found impossible, however, to keep EHPRG as an affiliated (or associated) section in CMD, many members of EHPRG not being individual members of EPS.

The relations are now fixed on the following basis:

Both organizations, CMD and EHPRG, have different aims and different rules. They feel that they should keep a friendly relationship based on their common interests in furthering science by organizing scientific conferences of high standards.

To keep close relations the groups decided to invite representatives to every meeting of their respective board or committee and to supply all documents to that representative, the representative having no power to vote. The EHPRG representative to the board of CMD will be an indivividual member of EPS.

About 80 members of CMD have indicated their interest in the activities of a High Pressure Section of CMD. As there will not be a special High Pressure Section these members will find notice of future meetings of EHPRG in the Meetings Calendar of Europhysics News. They will receive individual information upon registration as a member of EHPRG. At present the membership fee is $£ 1.00$ per year.

For the European High Pressure Research Group:

K.-F. Seifert, Chairman, Mineralogisch-Petrologisches Institut der Universität Bonn, Poppelsdorfer Schloss, D-53 Bonn, Fed. Rep. Germany.

For the European Physical Society: H.B.G. Casimir, President,

A. Guinier, Chairman CMD.

\section{European High Pressure Research Group}

\section{J. Lees, Harlow, UK T. Evans, Reading, UK}

The early nineteen-sixties saw a very considerable expansion both in the amount and in the range of high pressure research work being conducted in the European Area. This expansion was to be seen in Government, in University and Technical College, and in Industrial Laboratories. It was realised early that, in this difficult technological field, much was to be gained by bringing together scientists and engineers with different interests, to discuss the common problems of high pressure research. High pressure research, then as now, was an area where the traditional subject boundaries of science and engineering, had become rather blurred.

The foundation of our Research Group was laid in 1963 on an initiative taken by Standard Telecommunication Laboratories Ltd., in bringing together scientists and engineers of widely differing backgrounds for an informal meeting on the problems and discoveries of high pressure research. The success and enthusiasm of this first meeting led to the formation of a broadly-based interdisciplinary society, to organize two- and three-day research conferences, usually once per year, and moving around various centres of European High Pressure Research. From the beginning the emphasis in our organisation and our conferences has been on informality. No record is published of the proceedings (none is made), and we aim to have as much discussion as possible both in the sessions themselves and in informal 'get-togethers' of scientists during the course of the conferences. In accordance with our ideal of multidisciplinary approach, anyone can put forward a contribution for discussion on any subject in high pressures at any of our conferences. In the interest of maintaining some time for discussions however (and of 'fitting-in' with the programmes of other high pressure conferences) we usually announce a general theme for any particular meeting, which is related to the scientific activities of the local organizers.

It was originally believed that, as high pressure techniques became better understood, the need for organisations such as EHPRG would disappear. Our experience has been quite the reverse - enthusiasm today is higher than ever, and our membership, stands at the record level of more than 300. Our members are drawn from twelve European countries and represent a wide spectrum of research interests, covering all aspects of materials behaviour at high pressures. While the main activity of EHPRG is the organisation of its annual research conference, it also aims to co-operate with national high pressure associations such as the High Pressure Technology Association (HPTA) in the UK and the Groupe Français des Hautes Pressions (GFHP) in France, and with the international bodies such as the Association Internationale pour l'Avancement de la Recherche et de la Technologie aux Hautes Pressions (AIRAPT) and with the European Physical Society (EPS).

\section{UNIVERSITY OF NEW SOUTH WALES}

\section{PROFESSOR}

\section{OF THEORETICAL PHYSICS}

Applications are invited for appointment to a new Chair of Theoretical Physics in the School of Physics. Other chairs are held by Professor E. P. George, the present Head of School, Professor H.J. Goldsmid and Professor K. N. R. Taylor.

The main interests of the School are in solid-state physics, magnetic materials, surface physics and biophysics. There is also substantial research activity in atomic physics and acoustics. The new professor will supervise and participate in teaching and examining undergraduate and postgraduate students in the School and engage in and promote research and advanced study in the field of his chair. He will be expected to provide leadership for a theoretical physics group and will be encouraged to collaborate with the experimental physicists.

Salary \$A 19,102 per annum. Subject to the consent of the University Council, Professors may undertake a limited amount of higher consultative work. The University reserves the right to fill any chair by invitation.

For details and conditions of appointment write to Appointments Office, P.O. Box 1, Kensington, N.S.W. 2033, Australia. Applications close 28th June, 1974. 